\title{
The role of personality traits and online academic self-efficacy in acceptance, actual use and achievement in Moodle
}

\author{
Damian J. Rivers ${ }^{1}$
}

Received: 22 November 2020 / Accepted: 16 February 2021/ Published online: 2 March 2021

(C) The Author(s), under exclusive licence to Springer Science+Business Media, LLC part of Springer Nature 2021

\begin{abstract}
Informed by the educational conditions shaped by the novel coronavirus pandemic and an increased reliance upon online learning solutions and technologies, this article examines the role of personality traits and online academic self-efficacy in acceptance, actual use and achievement in Moodle on a socially distanced asynchronous university course in Japan. With a sample of 149 students the study adopts SEM path-analysis model testing procedures and shows that agreeableness and conscientious have positive direct effects on online academic self-efficacy in addition to positive indirect effects on the acceptance of Moodle. Moreover agreeableness and conscientious had an indirect effect on course achievement while none of the five-factor model personality traits had an influence on actual Moodle use. An improved respecified model further affirmed the importance of agreeableness and conscientious and their role in online academic selfefficacy, the acceptance and actual use of Moodle and course achievement outcomes. Fourteen percent of the observed variance in course achievement was explainable through the respecified model. The discussion highlights the implications to be drawn from the data in relation to the current educational landscape from the perspective of the educator.
\end{abstract}

Keywords Achievement $\cdot$ Moodle $\cdot$ Personality $\cdot$ Self-efficacy $\cdot$ Technology acceptance model

\section{Introduction}

Online education is now an established feature of higher education and the broader transnational student experience (Puska et al. 2020; Surry et al. 2005). Further

Damian J. Rivers

rivers@fun.ac.jp

1 Center for Meta-Learning, Future University Hakodate, Kamedanakano 116-2, Hakodate,

Hokkaido 041-8655, Japan 
opportunities have arisen in response to the novel coronavirus pandemic (Dhawan 2020). The United Nations (2020) states that the pandemic has prompted the "largest disruption of education systems in history, affecting nearly 1.6 billion learners in more than 190 countries and all continents" (p. 2). International and domestic students have been required to respond at short notice to the demands of socially distanced learning. A significant part of this response includes the online ecosystems through which educational materials are delivered. Learning Management Systems (LMSs) such as Blackboard and Moodle have been widely utilized alongside video conferencing technologies such as Zoom. Moodle is an open-source software and community of developers and one of the world's most used LMSs with a reported 238 million users across more than 235 countries (Moodle 2020). The move toward more ubiquitous online educational provisions draws attention to the complex relationship between humans and computers. Longstanding egalitarian concerns remain with evidence suggesting that online courses exacerbate inequalities (Marshall 2014). Online courses also have higher attrition rates than traditional face-to-face situations (Luyt 2013) due to incohesive working structures and peer-to-peer interactional routines (Dow 2008; Hrastinski 2009), misconceptions about cognitive load and lifestyle change demands (Bawa 2016). In terms of individual differences, or the stable psychological characteristics that distinguish individuals from each other, online learning solutions are known to appeal to certain personality profiles over others, often relative to learning style preferences (Bhagat et al. 2019; Kamal and Radhakrishnan 2019).

The acceptance of technology is an individual reaction. Theoretical support can be drawn from the Theory of Reasoned Action (TRA) (Ajzen and Fishbein 1980; Fishbein and Ajzen 1975) which incorporates personality traits (extraversion and neuroticism) as external variables effecting beliefs which underpin action (Agarwal and Prasad 1999). Informed by the TRA, the Technology Acceptance Model (TAM) (Davis 1989) provides an information-systems approach to assessing the adoption and acceptance of technology. The model is conceptualized on the premise that the perceived ease of use, perceived usefulness and attitude toward technology informs the continuance intention of the user. While the TAM has been validated across several studies (for meta-analyses see King and He 2006; Mortenson and Vidgen 2016; Schepers and Wetzels 2007; Scherer et al. 2019; Weerasinghe and Hindagolla 2018), only a small number of studies have examined the relationship between personality traits and technology acceptance. A limitation of the TAM is that both the continuance intention and actual use dimension are often self-reported (Abramson et al. 2015; Esteban-Millat et al. 2018; Liu et al. 2010; Nistor 2014; Straub et al. 1995). Although the TAM authors caution that such indicators "should not be regarded as precise measures" (Davis et al. 1989 , p. 991), this is nonetheless problematic as self-reported measures of intent are known to be unreliable in relation to actual behavior (Morwitz 2014).

Informed by the educational conditions being shaped by the novel coronavirus pandemic and an increased reliance on online learning solutions and technologies, this article examines the role of personality traits and online academic self-efficacy on the acceptance, actual use and achievement in Moodle within a compulsory 15-week socially distanced asynchronous university course in Japan. The current study contributes to the literature in three main areas. First, it adds to the small number of studies which link personality traits to the TAM (Svendsen et al. 2013). Second, the lack of Japan-based research identified by Granic and Marangunic (2019) and Murillo et al. 
(2020) is addressed by providing evidence from the Japanese context using Japanese language instruments. Finally, when technology use is compulsory such as it is within the current study, assessments of intent to use become somewhat redundant as course achievement is heavily dependent upon system use regardless of attitude. In a recent Moodle based TAM study the author concludes that future research should therefore make use of "objective usage data that are available in Moodle in the form of log files" (Yeou 2016, p. 313). Thus, the current study assesses actual usage log data drawn from Moodle. This article first provides background literature relevant to the variables being examined before then outlining the formal hypotheses to be tested within the research model. The methods employed within the current study are then detailed and the results presented. The discussion highlights the implications to be drawn from the results in relation to the current educational landscape from the perspective of the educator.

\section{Background literature}

\subsection{Technology acceptance model}

The purpose of the TAM is to "provide a basis for tracing the impact of external factors on internal beliefs, attitudes, and intentions" (Davis et al. 1989, p. 985) in relation to the acceptance of information systems. In the original conceptualization, the use of a system was drawn parallel to the theoretical principles of the TRA (Ajzen and Fishbein 1980; Fishbein and Ajzen 1975) in that motivations could be explained relative to the perceived ease of use, perceived usefulness and attitude (Davis 1986) (Fig. 1). The later TAM2 (Venkatesh and Davis 2000) extended the original model to explain perceived usefulness and usage intentions relative to social influence (subjective norm, voluntariness and image), and cognitive instrumental processes (job relevance, output quality and result demonstrability). The TAM and the TAM2 regularly account for between $40 \%-60 \%$ of technology acceptance variance among users (Park 2009). Within the TAM a perceived ease of use is defined as "the degree to which the prospective user expects the target system to be free of effort" whereas perceived usefulness refers to "the prospective user's subjective probability that using a specific application will increase his or her job performance within an organizational context" (Davis et al. 1989, p. 985). The perceived ease of use and perceived usefulness components reflect cognitive responses to using technology which then influence an affective response through (Holden and Rada 2011). While the relationships between the variables have been described as robust (Legris et al. 2003; Venkatesh and Davis 2000) certain studies have challenged the significance of the relationship between perceived ease of use and perceived usefulness (Venkatesh 2000), the relationship between perceived ease of use and attitude (Park 2009; Saade et al. 2007) and between perceived ease of use and frequency of use (Adams et al. 1992).

The TAM has been applied to a range of systems including mobile gaming (Ha et al. 2007), advertisements in social media (Lin and Kim 2016) and driverless vehicles (Koul and Eydgahi 2018). Within education the TAM has been used to assess the acceptance of MOOCs (Alraimi et al. 2015; Wu and Chen 2017; Zhou 2016) and learning management systems (Alharbi and Drew 2014; Mafuna and Wadesango 2016; Ngai et al. 2007; Van Raaij and Schepers 2008). The first TAM studies concerning 


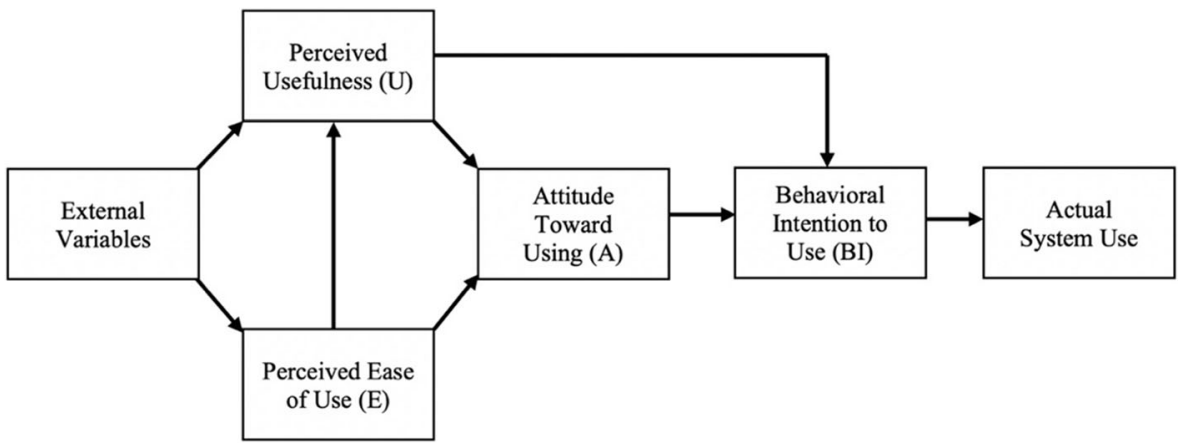

Fig. 1 The Technology Acceptance Model (TAM) (Davis et al. 1989)

Moodle were in 2009 since which time research interest has grown with a peak in 2019 (Murillo et al. 2020). TAM studies have been drawn from diverse educational contexts. In a Spanish university Sanchez and Hueros (2010) found that Moodle usage was directly influenced by a perceived ease of use and attitude. Similarly, EscobarRodriguez and Monge-Lozano (2012) found that the perception of Moodle as being easy to use had a positive effect on the continuance intention. At a Slovenian university Sumak et al. (2011) report that perceived usefulness was the strongest predictor of attitudes toward using Moodle and that Moodle use was dependent on behavioral intentions and attitudes. The authors state that "students like to use Moodle if they have good feelings about the usefulness of Moodle in getting better grades and knowledge" (p. 98). In universities in Serbia, Lithuania, and Bosnia and Herzegovina, Damnjanovic et al. (2015) drew from the attitudinal component of TAM to affirm that "if students have a positive view of Moodle, they will intend to use it in the future" (p. 508). At a Ghanaian university Essel and Apeanti (2017) found that perceived usefulness was the primary indicator of Moodle use. More recently, Huang et al. (2017) used the TAM to model Moodle acceptance intentions among university students in Macau and found that "students were inclined to use Moodle when they perceived or were convinced that it was a robust, innovative, easy, and useful platform" (p. 761). These studies suggest that the conceptual TAM is a reliable and valid predictor of technology acceptance within the field of education.

\subsection{Personality traits, self-efficacy and achievement}

Personality traits and self-efficacy beliefs are "both crucial to account for academic achievement, as for many other performances, although they address different structures and processes and operate at different levels and at different distance from academic performance" (Caprara et al. 2011, p. 79). Personality traits reflect "dimensions of individual differences in tendencies to show consistent patterns of thoughts, feelings, and actions" (McCrae and Costa 1990, p. 29). While there is considerable research into the relationship between personality traits and academic achievement (Bergold and Steinmayr 2018; De Feyter et al. 2012; Kappe and Van der Flier 2012), fewer works exist into the relationship between personality and technology acceptance. Early personality research focused on the reporting of arbitrary lists of traits believed to contribute to the individual although this was replaced with an interest in the 
development of fixed-factor solutions. Within mainstream personality literature, five superordinate constructs representing a five-factor model (Costa and McCrae 1985; Digman 1990) have dominated the research landscape. The five-factor model of personality is widely acknowledged as "a robust and comprehensive taxonomy of individual differences in personality' (Olesen et al. 2010, p. 538) and "the most widely used and empirically supported model of normal personality traits" (Chmielewski and Morgan 2013, p. 803).

In contrast to personality traits, self-efficacy beliefs relate to an individual's "confidence in their ability to organize and execute a given course of action to solve a problem or accomplish a task" (Eccles and Wigfield 2002, p. 110). While personality traits reflect stable individual characteristics deriving from genetic endowment, selfefficacy beliefs are malleable and subject to educational intervention. This corresponds to the view that self-efficacy is situational rather than a stable trait. In other words, whereas personality traits are somewhat unconditional behavioral tendencies, selfefficacy beliefs are context dependent knowledge structures that reference the ability to learn from experience and reflection (Caprara et al. 2011). A number of TAM studies have positioned self-efficacy beliefs as an external variable (Holden and Rada 2011) although a greater number of studies have focused on computer self-efficacy (Park 2009; Sanchez and Hueros 2010; Yeou 2016). Computer self-efficacy, as distinct from general academic self-efficacy, has been defined as "the confidence in one's ability to perform certain learning tasks using an e-learning system" (Pituch and Lee 2006, p. 226). Computer self-efficacy is therefore akin to digital literacy beliefs rather than beliefs directly concerned academic abilities.

Within information systems behavioral research, McElroy et al. (2007) identifies the five-factor personality model as a possible predictor of behavioral intent. Rosen and Kluemper (2008) explain the behavioral intention to use Facebook through the relationship between extroversion and perceived ease of use, extroversion and perceived usefulness and conscientiousness and perceived ease of use. Devaraj et al. (2008) investigated the relationship between five-factor personality constructs and TAM and found that extraversion moderated the relationship between subjective norms and an intention to use. Agreeableness was positively associated with perceived usefulness in addition to moderating the relationship between subjective norms and intention to use. Conscientiousness moderated the relationship between perceived usefulness and intention to use. Neuroticism was negatively associated with perceived usefulness while openness was positively associated with perceived usefulness. Zhou and Lu (2011) examined the effect of personality on user acceptance of mobile commerce using the perceived usefulness and continuance components from the TAM and found that emotional stability had a positive effect on perceived usefulness.

In a TAM study on the acceptance of computer-based assessments, Terzis et al. (2012) reports that neuroticism had a negative effect on perceived usefulness, while agreeableness and conscientiousnes had a positive effect perceived ease of use. Extroversion and openness also had a positive effect on the perceived importance of the technology. Wang et al. (2012) draw from the TAM to explain the role of personality in instant messaging continuance although none of the five-factor personality traits were significant predictors of perceived usefulness. Svendsen et al. (2013) examined the relationship between personality traits and behavioral intent when mediated through components of the TAM. The authors found that the mediation effect was 
only partial and that the personality of trait of emotional stability (i.e. positive neuroticism) had a direct effect on behavioral intent in terms of a stated intention to use technology. The relationship between extraversion, conscientiousness and behavioral intent was fully mediated by the TAM whereas the other personality variables were not. Barnett et al. (2015) used the five-factor model to predict perceived and actual usage of technology and found that conscientiousness and emotional stability were associated with perceived and actual use of technology. Several other studies have established direct effects between personality and the TAM although these studies have used personality traits outside of the five-factor model (e.g. Agarwal and Karahanna 2000; Nov and Ye 2009).

\section{Hypotheses and research model}

The current study examines the role of personality traits and online academic selfefficacy in acceptance, actual use and achievement in Moodle. The personality traits used are extraversion, agreeableness, conscientiousness, neuroticism and openness to experience (Goldberg 1993; John and Srivastava 1999). Extraversion represents a tendency to be energetic, sociable, lively, assertive and to experience positive thoughts and emotions. Extraverted individuals are inherently social and outgoing and are therefore more likely to be self-confident and assured. The links between extraversion and academic achievement have been mixed with positive, negative and insignificant results being commonplace. Extraversion has been linked to higher levels of achievement on tasks that require social interaction (Barrick and Mount 1991). Online learning in Moodle presents a challenge for extraverted individuals who "are left with fewer cues indicating that they are involved in a learning community and may instead view themselves as isolated" (Johnson et al. 2008). Socially distanced online learning is not anticipated to be conducive to the needs and desires of extraverted individuals due to the absence of an immediate social presence of others (Short et al. 1976).

H1: Extraversion has a positive direct effect on online academic self-efficacy (H1a), a negative indirect effect on the acceptance of Moodle (H1b), a negative indirect effect on actual Moodle use (H1c) and a negative indirect effect on course achievement (H1d).

Agreeableness concerns the control of interpersonal frustration. It is inclusive of prosocial attitudes, a sense of altruism and expressions of sympathy and trust (Finch and Graziano 2001; Graziano and Eisenberg 1997). Agreeableness is a reliable indicator of classroom attendance, cooperation (Lounsbury et al. 2003) and compliance with teacher instructions (Vermetten et al. 2001). Agreeableness is a trait suited to situations in which teamwork, collaboration and cooperation are required. Agreeableness is indicative of being more accommodating to change and unexpected circumstance (Asendorpf and Wilpers 1998; Cote and Moskowitz 1998) although it also has less of an impact on academic achievement than other personality traits (Poropat 2009). Socially distanced online learning is expected to provide agreeable students with an attractive alternative to the demands of face-to-face encounters. 
H2: Agreeableness has a positive direct effect on online academic self-efficacy (H2a), a positive indirect effect on the acceptance of Moodle (H2b), a positive indirect effect on actual Moodle use (H2c) and a positive indirect effect on course achievement (H2d).

Conscientiousness concerns the acceptance of responsibility and the strict adherence to principles. It involves being disciplined, organized and dependable. Conscientious individuals have an intrinsic motivation for achievement and an ability to selfdiscipline through persistent goal-orientated action (Costa et al. 1991; Poropat 2009). Kappe and van der Flier (2012) frame conscientiousness as the most consistent predictor of academic achievement. Conscientiousness correlates with higher levels of self-efficacy beliefs (Lee and Klein 2002) and more effective learning styles (Duff et al. 2004). Conscientious students are aware of what is needed to achieve success (Bidjerano and Yun Dai 2007; Komarraju et al. 2009). As conscientious individuals tend to have fixed achievement goals, changes in circumstance are unlikely to detract from their ability and desire to work efficiently toward the achievement of goals. Socially distanced online learning is anticipated to provide conscientious students with a clear pathway toward achievement and success.

H3: Conscientiousness has a positive direct effect on online academic self-efficacy (H3a), a positive indirect effect on the acceptance of Moodle (H3b), a positive indirect effect on actual Moodle use (H3c) and a positive indirect effect on course achievement $(\mathrm{H} 3 \mathrm{~d})$.

Neuroticism indicates the predisposition to experience psychological distress in the form of negative emotions and the negative framing of experience (McCrae and Costa 2008). While some studies have found negative connections between neuroticism and academic performance most studies report non-significant findings (Martin et al. 2006). It is believed that neuroticism is unable to predict academic achievement over cognitive ability (Ridgell and Lounsbury 2004). Emotional Stability (reverse neuroticism) refers to individuals who are stable and well-adjusted as opposed to anxious, self-conscious, tense and prone to the influence of negative emotions. Low emotional stability is disruptive to task performance and directly impacts beliefs concerning behavior and motivation. Individuals low in emotional stability are "likely to view technological advances in their work as threatening and stressful" (Devaraj et al. 2008, p. 97). The unstable conditions surrounding socially distanced learning are anticipated to contribute toward these feelings while also undermining self-efficacy beliefs.

H4: Emotional stability has a positive direct effect on online academic selfefficacy (H4a), a positive indirect effect on the acceptance of Moodle (H4b), a positive direct effect on actual Moodle use (H4c) and a positive indirect effect on course achievement (H4d).

As a trait associated with creativity and divergent thinking, individuals who are open to new experiences are curious and willing to try new and different things. Openness is a significant correlate of academic achievement (Asendorpf and Van Aken 2003) and has been linked to outcome grades and critical thinking (Komarraju and Karau 2005). 
Individuals who are open welcome change and have been shown to engage in varied learning experiences (Barrick et al. 2002). Individuals low in openness are resistant to change and prefer things to remain constant (Nov and Ye 2009). Openness frames new situations as positive and exciting rather than as threatening. The socially distanced learning environment and online experience is anticipated to be welcomed as a challenge.

H5: Openness has a positive direct effect on online academic self-efficacy (H5a), a positive indirect effect on the acceptance of Moodle (H5b), a positive direct effect on actual Moodle use (H5c) and a positive indirect effect on course achievement (H5d).

Within academic contexts self-efficacy references an individual belief that one can manage, complete and achieve success. These beliefs demand self-reflection and selfexamination (Bandura 1997). Self-efficacy beliefs are central to motivation and the development of outcome expectations, via personal and environmental attributions and appraisals. Self-efficacy beliefs, under the influence of personality traits, can be expected to inform the choices individuals make and the behavioral actions pursued (Pajares and Schunk 2002). Caprara et al. (2011) describe how "self-efficacy beliefs may mediate, at least in part, the influence of basic traits on specific abilities and performances, by sustaining the cognitive, affective and motivational processes leading to successful performance" (p. 79).

H6: Online academic self-efficacy has a positive direct effect on perceived ease of use (H6a), a positive direct effect on perceived usefulness (H6b), a positive indirect effect on actual Moodle use (H6c) and a positive indirect effect on course achievement (H6d).

The hypotheses stated and the research model shown in Fig. 2 suggest that personality traits influence the acceptance of Moodle through online academic self-efficacy beliefs which represent cognitive processes used to determined motivational intent (Barrick et al. 2002). Figure 2 further shows how the acceptance of Moodle within a compulsory socially distanced asynchronous course is expected to inform actual Moodle use. As actual Moodle use is believed to reflect greater interactional involvement with the course materials and activities (as assessed through objective Moodle log data) it is expected to then manifest through greater course achievement outcomes.

\section{Methods}

\subsection{Context and participants}

The research context was an information science university in northern Japan during novel coronavirus restrictions in which students were prohibited from attending the university. The socially distanced teaching semester was undertaken online while students were situated around Japan. During the semester, sophomore students enrolled within an asynchronous 15 -week communications course were invited to participate in 


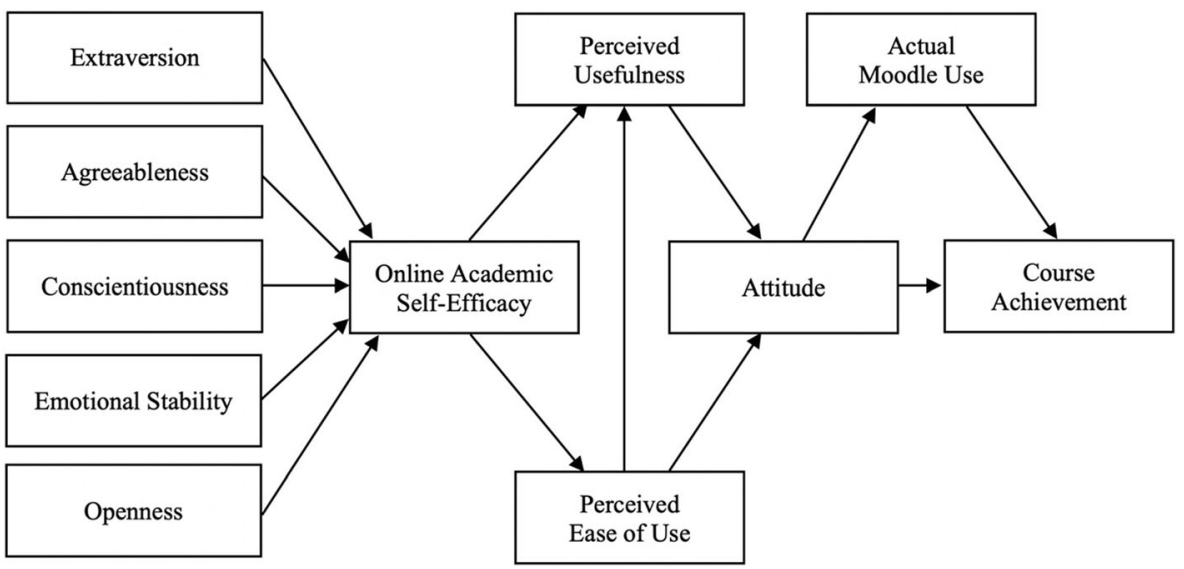

Fig. 2 The hypothesized model (H1-H6) of direct interactions to be tested (indirect effects and specific path notations are not shown for clarity)

the current study via email contact. A total of 149 compete responses were gathered (response rate 62\%). This sample included 119 (79.8\%) male and 30 (20.2\%) female students with an average age of $19.4(\mathrm{SD}=0.76)$ years old. Gender was not a variable controlled for within the current study although the observed gender ratio is representative of the wider university population. All consenting students were of Japanese nationality and all communications were undertaken in Japanese.

\subsection{Instrument}

A composite web-based Japanese language instrument was used. The Ten-Item Personality Inventory (TIPI) (Gosling et al. 2003) is a reliable and economical measure of the five-factor model personality traits. The TIPI shows adequate levels of convergence, test-retest reliability, predicted correlation patterns and convergence between observed and self-rated outcomes (see Gosling et al. 2003). The TIPI presents users with 10 pairs of character descriptors introduced by the statement "I see myself as...". Respondents are required to score each pair of descriptors on a scale of 1 "disagree strongly" to 7 "agree strongly". The average score of each pair is then calculated after reverse-scored items are recoded. A single composite score for each of the five-factor model personality traits is thereby created. The TIPI has been translated into several languages and validated in different cultural contexts. The Japanese version (TIPI-J) was developed Oshio et al. (2012) was used in the current study and has most recently been validated by Kawamoto et al. (2015) and Iwasa and Yoshida (2018).

A measure of online academic scale efficacy was created from the self-efficacy scale used in the Motivated Strategies for Learning Questionnaire (MSLQ) (Pintrich and De Groot 1990). The scale was edited to reference the online learning environment and consisted of three items regarding comparative perceptions of student status, study skills and subject knowledge. Technology acceptance was measured with six items pertaining to the perceived ease of use and perceived usefulness of Moodle. These were modified from previous TAM studies (e.g. Ngai et al. 2007; Yeou 2016). Three items pertaining to attitude were derived from Ajzen and Fishbein (1980). All items were 
assessed on a seven-point scale from 1 "disagree strongly" to 7 "agree strongly". In order to ascertain actual Moodle usage across the course, and as an experimental variable, Moodle data logs were extracted for each student in relation to the number of times the course was viewed and the number of times a post was made within one of the task forums or discussions. Within educational studies log data has been used to link learner behavior to performance in online course persistence (Morris et al. 2005) and learning management system achievement (You 2016) although in general log data has been underutilized (Romero et al. 2008). The course achievement measure was scaled from the raw standardized grade awarded at the end of the asynchronous course. The grades were reflective of student performance on various tasks, activities and discussions spread across a 15 -week semester. The grades given were standardized and agreed upon by three instructors. Therefore, the course achievement measure used in the current study stands as and the official university record for each individual student.

\subsection{Analysis}

Descriptive statistics for the variables were first assessed (Table 1). The data was processed for missing responses, outliers and univariate normality violations based on $\mathrm{a}+2 /-2$ skew and kurtosis range (George and Mallery 2010). A confirmatory factor analysis (CFA) was then performed with SPSS AMOS 27. The exogenous personality trait variables are not intended to be subject to alpha reliability tests or CFA procedures and were not included. The creator of the TIPI outlines how the measure is a short instrument that has optimized validity (including content validity) (Gosling et al. 2003). In terms of comparative reliability based on TIPI norms derived from 134,621 respondents between 15 and 20 years of age (Gosling et al. 2014), the personality traits within the current sample showed expected similarities and differences. The Japanese students in the current sample were less extraverted (current $=3.79$, norm $=3.92$ ), less conscientious (current $=3.57$, norm $=4.46$ ), less emotionally stable $($ current $=3.75$, norm $=$ 4.34 ), less open (current $=4.22$, norm $=5.50$ ) but more agreeable (current $=4.96$, norm $=4.60$ ). Previous cross-cultural personality studies have found that Japanese respondents have one of the world's highest levels of neuroticism (Lynn and Martin 1995) in addition to low openness and conscientiousness rankings (Mottus et al. 2012; Schmitt et al. 2007). These findings relate to cultural standards such as the culturespecific trait of understating one's own abilities as a means of avoiding attention in relation to the highest cultural expectations of perfection.

Assessments of model fit were made using the chi-square, normed chi-square, goodness of fit index (GFI), comparative fit index (CFI) and the root mean squared error of approximation (RMSEA) with $90 \%$ confidence intervals. Construct reliability was affirmed through item loadings greater than 0.50 (Chin 1998) with the exception of the "number of course posts made over the 15-week duration" $(0.498)$ which is part of the experimental actual Moodle use measure created from raw log data. Internal consistency is demonstrated through Cronbach's Alpha values greater than 0.70 (Hair et al. 1998) although values as low as 0.60 are acceptable with exploratory variables such as the actual Moodle use construct. In establishing construct validity Fornell and Larcker (1981) recommend that average variance extracted (AVE) values exceed 0.50 and composite reliability (CR) values exceed 0.70 . These standards were met across all variables (Table 2). 
Table 1 Descriptive Statistics $(n=149)$

\begin{tabular}{lll}
\hline Construct & Mean & Std. Deviation \\
\hline Extraversion & 3.78 & 1.29 \\
Agreeableness & 4.97 & 1.07 \\
Conscientiousness & 3.57 & 1.34 \\
Emotional Stability & 3.72 & 1.29 \\
Openness & 4.21 & 1.20 \\
Online Academic Self-Efficacy & 3.35 & 1.09 \\
Perceived Ease of Use & 5.13 & 1.32 \\
Perceived Usefulness & 4.74 & 1.44 \\
Attitude & 4.19 & 1.36 \\
Actual Moodle Use & 3.94 & 1.82 \\
Course Achievement & 3.85 & 2.08 \\
\hline
\end{tabular}

Discriminant validity was affirmed through the square root of the average variance extracted for each construct being greater than the off-diagonal loadings in the factor correlation matrix (Table 3). Kline (2005) notes that "the term structural equation modeling (SEM) does not designate a single statistical technique but instead refers to a family of related procedures" (p. 9). The SEM procedure used within the current study was path-analysis which can be likened to a form of multiple regression which focuses upon causality between observed variables. The current study satisfies minimum sample size requirements based on the ratio of participants to survey items and/or the number of variables used. However, it has been suggested that "determining an appropriate sample size based on a rule of thumb, such as 10 observations per parameter to be estimated, or a minimum of 200 observations, would seem insufficient under many circumstances" (Jackson 2007, p. 73). Bootstrapping (2000 samples, 95\% CI) with bias-corrected confidence estimates were used (Preacher and Hayes 2008).

Although the initial model did not fit the data to an acceptable level across all fit indices $[\chi 2=76.611(38), \mathrm{p}=0.001, \mathrm{NC}=1.885$, GFI $=0.92, \mathrm{CFI}=0.85$, RMSEA $=$ $0.07(90 \% \mathrm{CI} ; 0.049,0.105)]$, the model was sufficient for the purpose of affirming or rejecting the stated hypotheses (Table 4 and Fig. 3). In relation to the effect of personality traits on online academic self-efficacy $\mathrm{H1a}, \mathrm{H} 4 \mathrm{a}$ and $\mathrm{H} 5 \mathrm{a}$ are rejected while $\mathrm{H} 2 \mathrm{a}$ and $\mathrm{H} 3 \mathrm{a}$ are accepted as agreeableness and conscientious had a positive direct effect on online academic self-efficacy. The role of the five personality traits was also assisted through their indirect effect on the acceptance of Moodle in relation to its cognitive (perceived ease of use and perceived usefulness) and affective (attitudes) components. Extraversion, emotional stability and openness had no indirect effects on the acceptance of Moodle. H1b, $\mathrm{H} 4 \mathrm{~b}$ and $\mathrm{H} 5 \mathrm{~b}$ are therefore rejected. In contrast, agreeableness, and to a greater degree of strength, conscientiousness had positive indirect effects on the acceptance of Moodle thus leading to the acceptance of $\mathrm{H} 2 \mathrm{~b}$ and H3b. None of the personality traits were able to exert influence on actual Moodle use. $\mathrm{H} 1 \mathrm{c}-\mathrm{H} 5 \mathrm{c}$ are rejected. 
Table 2 CFA item loadings, construct reliabilities and convergent validity

\begin{tabular}{|c|c|c|c|c|c|}
\hline Construct & Item (original presented in Japanese) & Loading & AVE & CR & CA \\
\hline \multirow[t]{4}{*}{ Online Academic Self-Efficacy } & & & .521 & .764 & .759 \\
\hline & $\begin{array}{l}\text { I consider myself to be a better student } \\
\text { than my online classmates. }\end{array}$ & .688 & & & \\
\hline & $\begin{array}{l}\text { I think my online study skills are better } \\
\text { than other students. }\end{array}$ & .803 & & & \\
\hline & $\begin{array}{l}\text { I think I know a lot more about a subject } \\
\text { than my online classmates. }\end{array}$ & .668 & & & \\
\hline \multirow[t]{4}{*}{ Perceived Ease of Use } & & & .716 & .883 & .883 \\
\hline & $\begin{array}{l}\text { The process of using Moodle is clear and } \\
\text { understandable. }\end{array}$ & .833 & & & \\
\hline & $\begin{array}{l}\text { It is easy for me to become skilful in using } \\
\text { Moodle. }\end{array}$ & .881 & & & \\
\hline & Overall, I believe that Moodle is easy to use. & .825 & & & \\
\hline \multirow[t]{4}{*}{ Perceived Usefulness } & & & .779 & .913 & .913 \\
\hline & $\begin{array}{l}\text { Using Moodle improves my productivity } \\
\text { in the course. }\end{array}$ & .897 & & & \\
\hline & $\begin{array}{l}\text { Using Moodle enhances the effectiveness } \\
\text { of my learning. }\end{array}$ & .919 & & & \\
\hline & $\begin{array}{l}\text { Overall, I find Moodle to be useful } \\
\text { for my learning. }\end{array}$ & .831 & & & \\
\hline \multirow[t]{4}{*}{ Attitude } & & & 676 & .862 & .859 \\
\hline & Using Moodle is fun. & .841 & & & \\
\hline & $\begin{array}{l}\text { Moodle provides an attractive learning } \\
\text { environment. }\end{array}$ & .754 & & & \\
\hline & Overall, I like using Moodle. & .869 & & & \\
\hline \multirow[t]{3}{*}{ Actual Moodle Use } & & & .545 & .704 & .644 \\
\hline & $\begin{array}{l}\text { Number of course views made over } \\
\text { the } 15 \text {-week duration. }\end{array}$ & .955 & & & \\
\hline & $\begin{array}{l}\text { Number of course posts made over } \\
\text { the } 15 \text {-week duration. }\end{array}$ & .498 & & & \\
\hline
\end{tabular}

Notes: $\mathrm{AVE}=$ Average Variance Extracted, $\mathrm{CR}=$ Composite Reliability, $\mathrm{CA}=$ Cronbach's Alpha. Method ML; Model fit: $[\chi 2=114.503(67), \mathrm{p}=0.000, \mathrm{NC}=1.709, \mathrm{TLI}=0.94, \mathrm{CFI}=0.95, \mathrm{RMSEA}=0.06(90 \% \mathrm{CI}$; $0.047,0.090)]$

Finally, and consistent with the patterns established, only agreeableness and conscientious were able to exert an indirect effect on course achievement. This leads to the rejection of $\mathrm{H} 1 \mathrm{~b}, \mathrm{H} 4 \mathrm{~d}$ and $\mathrm{H} 5 \mathrm{~d}$ and the acceptance of $\mathrm{H} 2 \mathrm{~d}$ and $\mathrm{H} 3 \mathrm{~d}$. Actual Moodle use is an ineffective bridge between attitude and course achievement. That is, on a compulsory course which demands that all students use Moodle across the 15-week period for all tasks and activities, actual Moodle use is a positive indicator of course achievement regardless of attitudes shown toward the technology. Concerning the role of online academic self-efficacy, a direct effect on perceived ease of use and perceived usefulness were observed. H6a and H6b are accepted. Consistent with the effects of personality, online academic self-efficacy had no effect on actual Moodle use but it did 
Table 3 Construct correlations and discriminant validity

\begin{tabular}{llllllllllll}
\hline Construct & 1 & 2 & 3 & 4 & 5 & 6 & 7 & 8 & 9 & 10 & 11 \\
\hline 1. EXTR & - & & & & & & & & & \\
2. AGRE & -.166 & - & & & & & & & & \\
3. CONS & -.006 & .017 & - & & & & & & & \\
4. EMOS & .071 & .133 & .271 & - & & & & & & & \\
5. OPEN & .325 & -.022 & -.019 & .318 & - & & & & & \\
6. OAS & .078 & .190 & .318 & .037 & .077 & $\underline{.72}$ & & & & \\
7. PEU & -.082 & .202 & .190 & -.026 & -.019 & .225 & $\underline{.84}$ & & & \\
8. PU & -.028 & .161 & .097 & -.054 & -.117 & .287 & .383 & $\mathbf{. 8 8}$ & & & \\
9. ATT & .132 & -.020 & .077 & -.083 & -.034 & .241 & .340 & .635 & $\underline{.82}$ & & \\
10. AMU & -.015 & -.055 & .280 & -.085 & -.001 & .326 & .192 & .125 & .086 & $\mathbf{. 7 3}$ & \\
11. CA & -.173 & .118 & .144 & -.107 & -.066 & .211 & .075 & .142 & .142 & .345 & - \\
\hline
\end{tabular}

Notes: $\mathrm{EXTR}=$ Extraversion, AGRE $=$ Agreeableness, CONS=Conscientiousness, EMOS = Emotional Stability, OPEN=Openness, OAS=Online Academic Self-Efficacy, PEU=Perceived Ease of Use, PU=Perceived Usefulness, $\mathrm{ATT}=$ Attitude, $\mathrm{AMU}=$ Actual Moodle Use, $\mathrm{CA}=$ Course Achievement. The bolded underlined diagonal values represent the square root of the average variance extracted (AVE)

have positive effect on course achievement. H6c is therefore rejected while H6d is accepted.

In order to better assess the role of personality traits, all non-significant paths were removed while four additional paths were entered for testing (Table 5) in judicious consultation with the post-hoc modification indices. A direct path was entered between extraversion and attitude, between conscientiousness and actual Moodle use, between online academic self-efficacy and actual Moodle use and between extraversion and grade. These paths reflected a more direct role for personality and online academic selfefficacy in relation to attitude, actual Moodle use and course achievement. The retested model provided a better fit to the data $[\chi 2=32.101(24), \mathrm{p}=0.125, \mathrm{NC}=1.338$, GFI $=$ $0.95, \mathrm{CFI}=0.95$, RMSEA $=0.04(90 \% \mathrm{CI} ; 0.000,0.087)]$ particularly in terms of explaining a greater proportion of the variance in the actual Moodle use variable which increased from $0 \%$ to $14 \%$.

The data shown in Table 5 (direct and indirect effects) and Fig. 4 (direct effects only) adds further support to the positive role of agreeableness and conscientiousness in terms of a direct effect on online academic self-efficacy and an indirect effect on the acceptance of Moodle. Moreover, both traits are significant indicators of actual Moodle use. The role of agreeableness is entirely indirect whereas the role of conscientiousness is both direct and indirect. Both personality traits also have indirect effects on course achievement. The respecified model was able to account for $14.6 \%$ of the variance observed within course achievement. These results suggest that socially distanced online learning with Moodle is more appealing to students who are high in agreeableness and conscientiousness. In contrast, while extraversion had a direct positive effect on attitude toward Moodle it had a direct negative effect on course achievement. The latter finding is more consistent with the original hypotheses and the assertion that socially distanced online learning is of lesser appeal to extraverted individuals. Online 


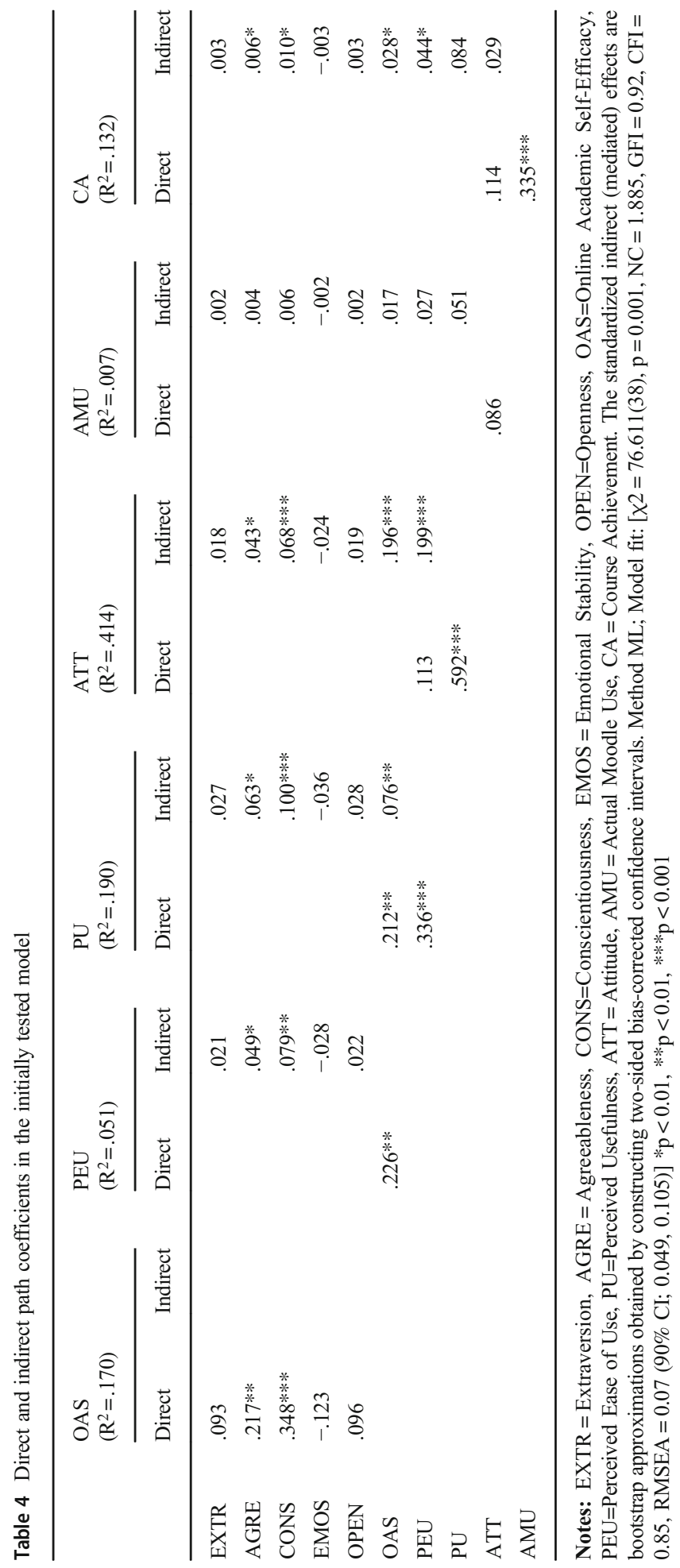




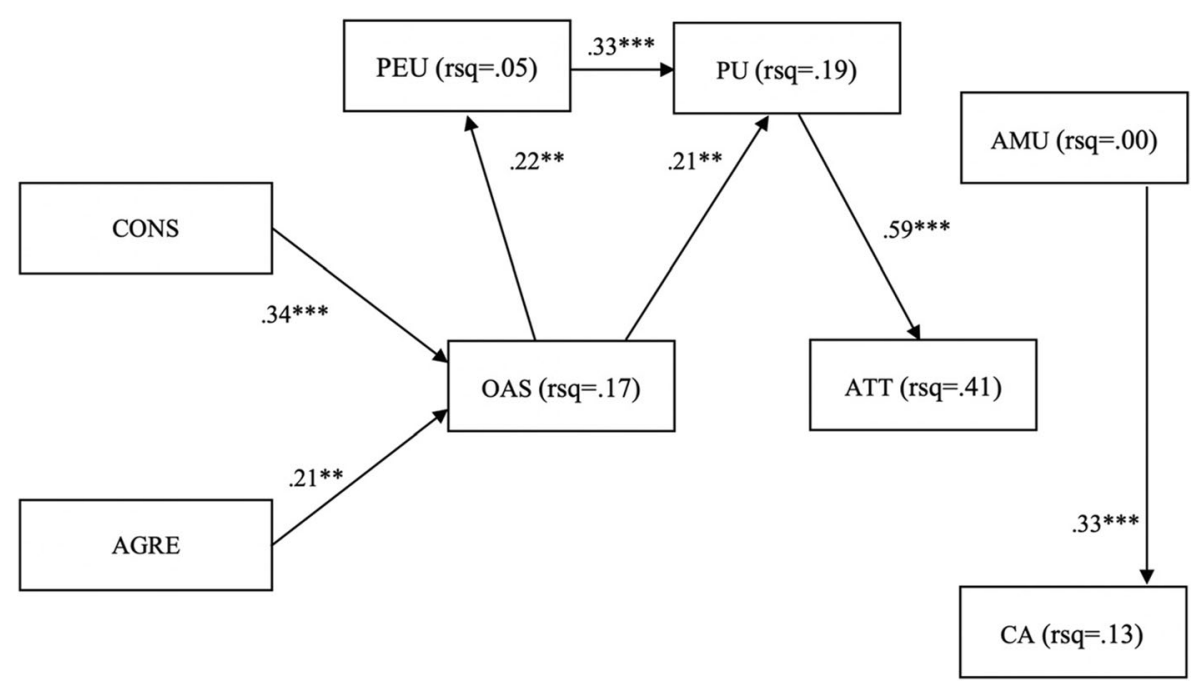

Fig. 3 Direct path coefficients in the initially tested model. Notes: AGRE=Agreeableness, CONS=Conscientiousness, OAS=Online Academic Self-Efficacy, PEU=Perceived Ease of Use, PU=Perceived Usefulness, ATT $=$ Attitude, AMU = Actual Moodle Use, CA = Course Achievement. Method ML; Model fit: $[\chi 2=76.611(38), \mathrm{p}=0.001, \mathrm{NC}=1.885, \mathrm{GFI}=0.92, \mathrm{CFI}=0.85, \mathrm{RMSEA}=0.07(90 \% \mathrm{CI}$; $0.049,0.105)] * \mathrm{p}<0.01, * * \mathrm{p}<0.01, * * * \mathrm{p}<0.001$ (insignificant paths removed)

academic self-efficacy had a positive direct effect on actual Moodle use which further suggests that actual system use is independent of the acceptance of technology.

\section{Discussion}

The current study has focused upon the use of a learning management system which has over 238 million users (Moodle 2020). The outcomes reported are therefore relevant to a wide range of educators and technologists interested in the dynamics of human-computer interactions. The primary findings reported concern the role of personality traits in the acceptance and use of technology. It has been shown that agreeableness and conscientious are the two most dominant traits in terms of their direct and indirect effect on the modelled interactions. The two traits had direct positive effects on online academic self-efficacy beliefs in addition to indirect positive effects on the perceived ease of use, the perceived usefulness, attitudes toward Moodle and online course achievement outcomes. It was earlier stated how agreeableness concerns the control of frustration meaning that agreeable students are perhaps less inclined to raise objection relating to their study environment. Previous studies have shown how such students are reliable attenders, cooperative (Lounsbury et al. 2003) and compliant with teacher instructions (Vermetten et al. 2001). The finding that agreeableness had an indirect effect on online course achievement is a finding not previously reported. It may be that the relative isolation from others provides agreeable students with a more harmonious and less competitive learning environment in which they are able to function more effectively. It can be suggested that agreeableness combined with higher 


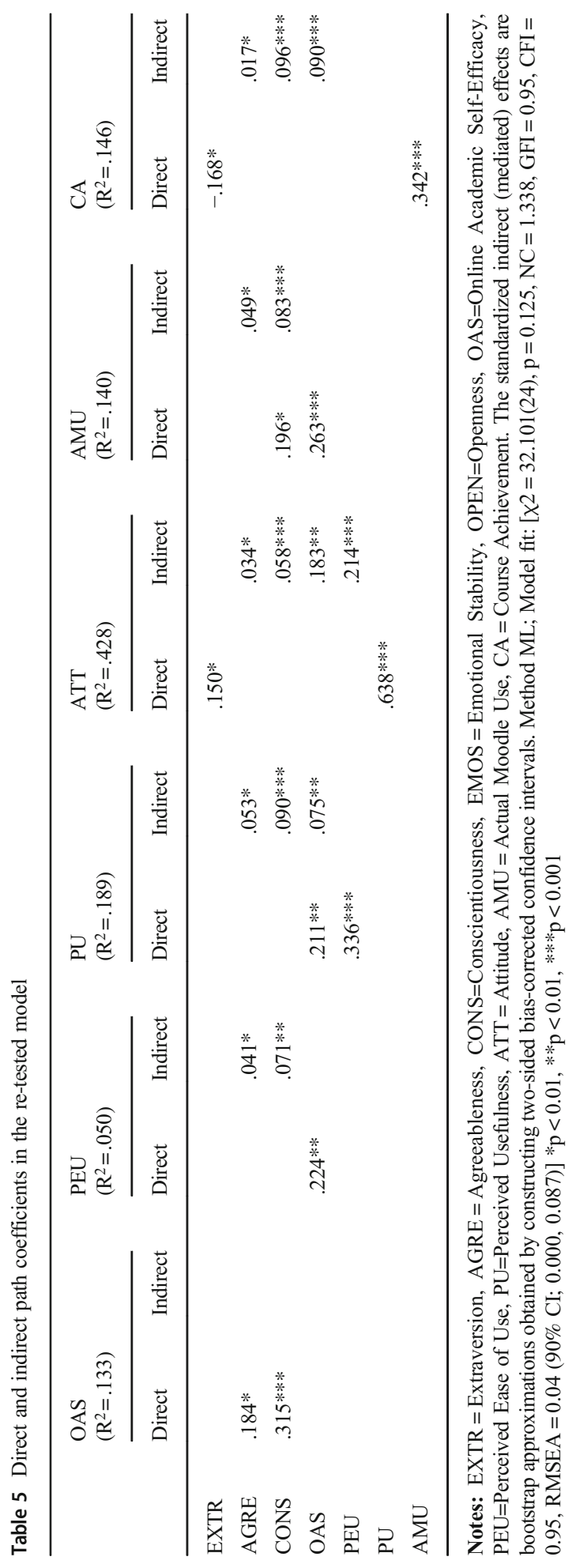




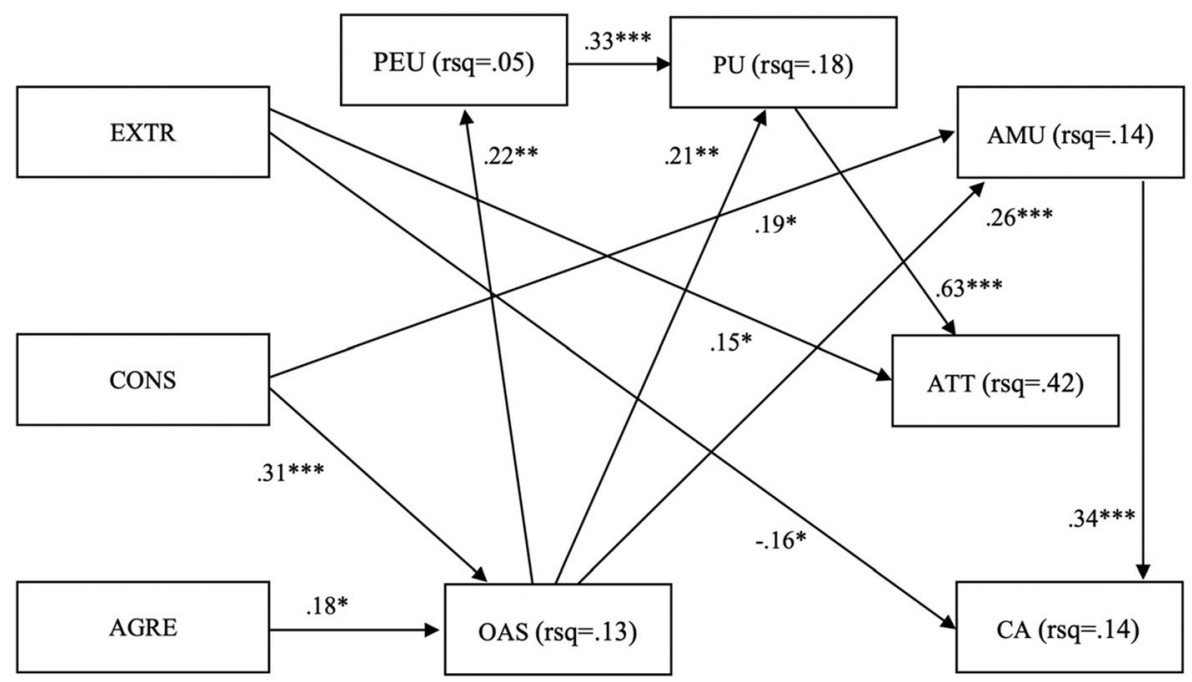

Fig. 4 Direct path coefficients in the re-tested model. Notes: EXTR = Extraversion, AGRE = Agreeableness, CONS=Conscientiousness, OAS=Online Academic Self-Efficacy, PEU=Perceived Ease of Use, $\mathrm{PU}=$ Perceived Usefulness, ATT $=$ Attitude, $\mathrm{AMU}=$ Actual Moodle Use, $\mathrm{CA}=$ Course Achievement. Method ML; Model fit: $[\chi 2=32.101(24), p=0.125, \mathrm{NC}=1.338, \mathrm{GFI}=0.95, \mathrm{CFI}=0.95, \mathrm{RMSEA}=0.04(90 \% \mathrm{CI}$; $0.000,0.087)] * \mathrm{p}<0.01, * * \mathrm{p}<0.01, * * * \mathrm{p}<0.001$ (insignificant paths removed)

levels of conscientiousness is a desirable combination within the context of socially distance online learning environments.

The stronger effect of conscientiousness on the aforementioned variables points toward its dominant position as the the most consistent predictor of academic achievement (Kappe and Van der Flier 2012) and as a trait which correlates with higher levels of self-efficacy beliefs (Lee and Klein 2002) and more effective learning styles (Duff et al. 2004). Within the current online learning environment there is significant emphasis placed on the need for effective self-regulation (Jansen et al. 2019). Pintrich (2000) defines self-regulated learning as "an active, constructive process whereby learners set goals for their learning and then attempt to monitor, regulate, and control their cognition, motivation, and behaviour, guided and constrained by their goals and the contextual features in the environment" (p. 453). Conscientious students can be expected to have the capacity to identify personal goals and use them as a motivational standard through which study related actions and decisions are referenced and controlled (Zimmerman 2000). Practical aspects of self-regulated learning such as strategic planning, time management and effort regulation are important for academic achievement (Puzziferro 2008) and would seem more important within the context of a compulsory socially distanced online learning environment.

The role of extraversion draws attention to the specific behavioral demands of learning online as opposed to within the face-to-face classroom. Extraversion represents a tendency to be energetic, sociable, lively, assertive and to experience positive thoughts and emotions. Within face-to-face learning situations, especially those which demands open interactions and exchanges through the sharing of opinions with teachers and peers, extraverted students are at a natural advantage due to being inherently social and outgoing. While these traits do not always lead to greater achievement outcomes on 
account of the observation that the same extraverted individuals are likely to place social needs above academic ones, the socially distanced online learning environment would appear to place such students at a disadvantage. These students "are left with fewer cues indicating that they are involved in a learning community and may instead view themselves as isolated" (Johnson et al. 2008). This view is highlighted within the re-tested model where extraversion has a direct negative effect on course achievement. While Japanese nationals have some of the highest ratings of neuroticism in the world (Lynn and Martin 1995), the current study provides support to the non-significant link between emotional stability and academic achievement (Martin et al. 2006). In contrast, the non-significant effect of openness throughout the tested model is not consistent with the literature that marks openness as a significant correlate of academic achievement (Asendorpf and Van Aken 2003). The effect patterns demonstrated by agreeableness and conscientious are generally replicated by online academic self-efficacy. This affirms the relationship between personality and self-efficacy as well as pointing toward an area in which educators can tailor their efforts in relation to the promotion of learning skills and greater self-regulated learning capabilities. These observations are given greater significance when noting that online academic self-efficacy beliefs had an indirect impact on course achievement larger than agreeableness and conscientious. Online academic self-efficacy can also be a reliable indicator of technology acceptance although as was found with personality, it cannot be viewed as a reliable indicator of actual Moodle use.

In terms of the primary variables within the TAM several interesting observations can be made. While online academic self-efficacy was an almost equal indicator of perceived ease of use and perceived usefulness, these two variables held strikingly different effects on attitudes toward Moodle. The perceived ease of use was a nonsignificant indicator whereas the perceived usefulness of Moodle had a strong positive effect on attitudes. The non-significant effect of perceived ease of use on attitude reflects previous findings (Lee et al. 2005; Park 2009; Saade et al. 2007). While much of this can be attributed to the compulsory nature of course (i.e. it is useful as the only means by which students can achieve), Adams et al. (1992) suggest that perceived ease of use might be "an important determinant of adoption but is less important in explaining the level of post-adoption usage" (p. 243). The students in the current study were not new to Moodle and had some experience using the system prior to the novel coronavirus restrictions. Questions can also be asked concerning the validity of the affective attitudinal component of TAM as to whether a positive attitude toward Moodle is predominantly shaped by the perceived usefulness of the technology. The correlation matrix in Table 3 suggests that these two variables are not entirely independent of one another. Attitudes toward Moodle accounted for the largest portion of shared variance within the model, yet it had no significant effect on either actual Moodle use or course achievement. What then is the practical value of having a positive attitude toward Moodle if it does not inform actual usage or achievement when used as the exclusive means of learning? Previous studies have found that positive attitudes toward technology effect the continuance intention, but such findings must be questioned due to issues of self-report bias and reliability. It is difficult to conceive of a valid explanation as to why in the current context positive attitudes toward Moodle do not then transfer into actual usage behaviors or achievement. These questions take on further significance when noting that actual Moodle use was a strong significant 
indicator of course achievement. Identifying a reliable indicator of actual Moodle use represents an area for future research exploration.

\subsection{Practical considerations and concerns}

Dhawan (2020) highlights how "pedagogical and technical competency of online educators is of utmost importance. Rigorous quality management programs and continuous improvement are pivotal for online learning success and making people ready for any crisis-like situation" (p. 18). The results discussed have implications for the provision of online education, particularly the socially distanced kind which have arisen in response to the novel coronavirus pandemic. In order to make such courses more inclusive to all individuals course creators and institutions need to identify how their programs can be more appealing for extraverted students through increasing the immediate social presence of others (Short et al. 1976) . Learner to learner interactions within online learning environments have been found as some of the most significant indicators of achievement (Macfadyen and Dawson 2012) as they promote learning via the intellectual stimulation and exchange of ideas (Agudo-Peregrina et al. 2014). Galikyan and Admiraal (2019) further report that "social presence moderates the relationship between cognitive presence and student academic performance. This implies that instructional interventions that are aimed at promoting student participation and interaction as well as diversifying interaction and increasing response rates in online discussion forums are desired" (p. 7). Asynchronous online discussion forums such as those commonplace in Moodle provide an outlet for such collaborative interactions to occur (Schrire 2006). A lack of dynamic social interaction and the presence of fixed routines established within asynchronous online courses place extraverted students at a disadvantage. Moreover, the modes of assessment used within such courses (i.e. static forums, reports, readings, multiple choice quizzes etc.) should be orientated toward more creative real-time formats to allow for sociable, lively and outgoing individuals to use their innate traits toward greater achievement outcomes.

Similar concerns can be raised in relation to traits such as openness. Variety in terms of materials, methods of assessment and interaction is vital for inclusion. While the trait of conscientiousness underpins all productive study behaviors as reflected in its position as the dominant personality indicator of achievement, traits such as agreeableness appear to be favored within courses such as the one used in the current study. Johnson et al. (2008) cautions that "e-learning success is not simply a matter of providing a rich set of technological opportunities, but instead technology must be seen as contributing to the learning success" (p. 365). To this end, online learning specialists need to base their technological solutions and interests on well-researched pedagogical principles with sound theoretical rationale used to direct and moderate the use of technology. In contexts such as Japan there remains a tendency among some educators to view Moodle use as a learning outcome rather than as a tool for the communication and assessment of more comprehensive learning objectives. Moodle plugins that undermine responsibility and adaptive self-regulated learning skills are often promoted as technological pacifiers to maladaptive behaviors in the absence of efforts which guide students toward achievement related improvement (see Johnson et al. 2017 for a context specific example). Such tech-dominant approaches need to be eradicated and replaced with diversified online solutions which attract and sustain topical interest 
while maintaining pedagogical integrity through the promotion of adaptive selfregulatory behaviors.

\subsection{Limitations}

While the current study has provided valuable interdisciplinary data from an understudied context there are several limitations which must be acknowledged. First, the participants within the current cannot be used to generalize beyond the immediate context which undermines the potential applicability of the results to other studies. Not only are cultural factors significant in shaping personality traits within the Japanese context but cultural etiquette also has a significant role on self-reported behaviors. Second, the TIPI is a practical measure of the five-factor model of personality and is not intended to possess the same psychometric properties as more extensive measures. While the TIPI has been validated in numerous studies it remains a substitute for the more traditional measures. Future studies that wish to focus on personality would therefore be advised to use more substantive measures although this creates additional issues with time demands, participation and drop-out rates.

\section{Conclusion}

Murillo et al. (2020) state that "there is scientific interest in understanding the acceptance and use of Moodle through the TAM model" (p. 12). Given the educational conditions being shaped by the novel coronavirus pandemic and the increased reliance upon online learning solutions and technologies, this article has examined the effect of personality traits and online academic self-efficacy on the acceptance, actual use and course achievement in Moodle on a compulsory 15-week socially distanced asynchronous university course in Japan. The study was devised in direct response to the learning conditions currently experienced and in relation to several gaps in the existing literature. It is hoped that the unique multidisciplinary data provided can serve as a basis for future replication and expansion within other effected educational contexts.

Acknowledgements Sincere gratitude and appreciation are expressed to Professor Michael Vallance and Associate Professor Michiko Nakamura for their professional discourse, cooperation and critical feedback.

\section{References}

Abramson, J., Dawson, M., \& Stevens, J. (2015). An examination of the prior use of e-learning within an extended technology acceptance model and the factors that influence the behavioral intention of users to use m-learning. SAGE Open, 5(4). https://doi.org/10.1177/2158244015621114.

Adams, D. A., Nelson, R. R., \& Todd, E. A. (1992). Perceived usefulness, ease of use, and usage of information technology: A replication. MIS Quarterly, 16(2), 227-248. https://doi.org/10.2307/249577.

Agarwal, R., \& Karahanna, E. (2000). Time flies when you're having fun: Cognitive absorption and beliefs about information technology usage. MIS Quarterly, 24(4), 665-694. https://doi.org/10.2307/3250951.

Agarwal, R., \& Prasad, J. (1999). Are individual differences germane to the acceptance of information technologies? Decision Sciences, 30(2), 361-391. https://doi.org/10.1111/j.1540-5915.1999.tb01614.x. 
Agudo-Peregrina, A. F., Iglesias-Pradas, S., Conde-Gonzalez, M. A., \& Hernandez-Garcia, A. (2014). Can we predict success from log data in VLEs? Classification of interactions for learning analytics and their relation with performance in VLE-supported F2F and online learning. Computers in Human Behavior, 31, 542-550. https://doi.org/10.1016/j.chb.2013.05.031.

Ajzen, I., \& Fishbein, M. (1980). Understanding attitudes and predicting social behavior. Prentice-Hall.

Alharbi, S., \& Drew, S. (2014). Using the technology acceptance model in understanding academics' behavioural intention to use learning management systems. International Journal of Advanced Computer Science and Applications, 5(1). https://doi.org/10.14569/IJACSA.2014.050120.

Alraimi, K. M., Zo, H., \& Ciganek, A. P. (2015). Understanding the MOOCs continuance: The role of openness and reputation. Computers \& Education, 80(1), 28-38. https://doi.org/10.1016/j.compedu.2014. 08.006.

Asendorpf, J. B., \& Van Aken, M. A. G. (2003). Personality-relationship transaction in adolescence: Core versus surface personality characteristics. Journal of Personality, 71(4), 629-666. https://doi.org/10.1111/ 1467-6494.7104005.

Asendorpf, J. B., \& Wilpers, S. (1998). Personality effects on social relationships. Journal of Personality and Social Psychology, 74(6), 1531-1544. https://doi.org/10.1037/0022-3514.74.6.1531.

Bandura, A. (1997). Self-efficacy: The exercise of control. W.H Freeman.

Barnett, T., Pearson, A. W., Pearson, R., \& Kellermanns, F. W. (2015). Five-factor model personality traits as predictors of perceived and actual usage of technology. European Journal of Information Systems, 24(4), 374-390. https://doi.org/10.1057/ejis.2014.10.

Barrick, M. R., \& Mount, M. K. (1991). The big five personality dimensions and job performance: A metaanalysis. Personnel Psychology, 44(1), 1-26. https://doi.org/10.1111/j.1744-6570.1991.tb00688.x.

Barrick, M. R., Stewart, G. L., \& Piotrowski, M. (2002). Personality and job performance: Test of the mediating effects of motivation among sales representatives. Journal of Applied Psychology, 87(1), 4351. https://doi.org/10.1037/0021-9010.87.1.43.

Bawa, P. (2016). Retention in online courses: Exploring issues and solutions: A literature review. SAGE Open, 6(1). https://doi.org/10.1177/2158244015621777.

Bergold, S., \& Steinmayr, R. (2018). Personality and intelligence interact in the prediction of academic achievement. Journal of Intelligence, 6(2), 27. https://doi.org/10.3390/jintelligence6020027.

Bhagat, K. K., Wu, L. Y., \& Chang, C. Y. (2019). The impact of personality on students' perceptions towards online learning. Australasian Journal of Educational Technology, 35(4). https://doi.org/10.14742/ajet. 4162.

Bidjerano, T., \& Yun Dai, D. (2007). The relationship between the big-five model of personality and selfregulated learning strategies. Learning and Individual Differences, 17(1), 69-81. https://doi.org/10.1016/ j.lindif.2007.02.001.

Caprara, G. V., Vecchione, M., Alessandri, G., Gerbino, M., \& Barbaranelli, C. (2011). The contribution of personality traits and self-efficacy beliefs to academic achievement: A longitudinal study. British Journal of Educational Psychology, 81(1), 78-96. https://doi.org/10.1348/2044-8279.002004.

Chin, W. W. (1998). The partial least squares approach to structural equation modelling. In G.A. Marcoulides (Ed.), Modern methods for business research (pp. 295-336). Lawrence Erlbaum.

Chmielewski, M. S., \& Morgan, T. A. (2013). Five-factor model of personality. In M.D. Gellman M.D and J.R. Turner (Eds.), Encyclopedia of behavioral medicine. Springer. https://doi.org/10.1007/978-1-44191005-9_1226.

Costa, P. T., \& McCrae, R. R. (1985). The NEO personality inventory manual. Psychological Assessment Resources.

Costa, P. T., McCrae, R. R., \& Dye, D. A. (1991). Facet scales for agreeableness and conscientiousness: A revision of the NEO personality inventory. Personality and Individual Differences, 12(9), 887-898. https://doi.org/10.1016/0191-8869(91)90177-D.

Cote, S., \& Moskowitz, D. S. (1998). On the dynamic covariation between interpersonal behavior and affect: Prediction from neuroticism, extraversion, and agreeableness. Journal of Personality and Social Psychology, 75(4), 1032-1046. https://doi.org/10.1037/0022-3514.75.4.1032.

Damnjanovic, V., Jednak, S., \& Mijatovic, I. (2015). Factors affecting the effectiveness and use of Moodle: Students' perception. Interactive Learning Environments, 23(4), 496-514. https://doi.org/10.1080/ 10494820.2013.789062.

Davis, F, D. (1986). A technology acceptance model for empirically testing new end-user information systems : Theory and results. Unpublished $\mathrm{PhD}$ dissertation. Massachusetts Institute of Technology. https:// dspace.mit.edu/handle/1721.1/15192.

Davis, F. D. (1989). Perceived usefulness, perceived ease of use, and user acceptance of information technology. MIS Quarterly, 13(3), 319-340. https:/www.jstor.org/stable/249008. 
Davis, F. D., Bagozzi, R. P., \& Warshaw, P. R. (1989). User acceptance of computer technology: A comparison of two theoretical models. Management Science, 35(8), 98-1003. https://doi.org/10.1287/ mnsc.35.8.982.

De Feyter, T., Caers, R., Vigna, C., \& Berings, D. (2012). Unraveling the impact of big five personality traits on academic performance: The moderating and mediating effects of self-efficacy and academic motivation. Learning and Individual Differences, 22(4), 439-448. https://doi.org/10.1016/j.lindif.2012.03.013.

Devaraj, S., Easley, R., \& Crant, J. (2008). How does personality matter? Relating the five-factor model to technology acceptance and use. Information Systems Research, 19(1), 93-105. https://www.jstor.org/ stable/23015423.

Dhawan, S. (2020). Online learning: A panacea in the time of COVID-19 crisis. Journal of Educational Technology Systems, 49(1), 5-22. https://doi.org/10.1177/0047239520934018.

Digman, J. M. (1990). Personality structure: Emergence of the five-factor model. Annual Review of Psychology, 41(1), 417-440. https://doi.org/10.1146/annurev.ps.41.020190.002221.

Dow, M. (2008). Implications of social presence for online learning: A case study of MLS students. Journal of Education for Library and Information Science, 49(4), 238-239. https://www.jstor.org/stable/40323753.

Duff, A., Boyle, E., Dunleavy, K., \& Ferguson, J. (2004). The relationship between personality, approach to learning and academic performance. Personality and Individual Differences, 36(8), 1907-1920. https:// doi.org/10.1016/j.paid.2003.08.020.

Eccles, J. S., \& Wigfield, A. (2002). Motivational beliefs, values, and goals. Annual Review of Psychology, 53, 109-132. https://doi.org/10.1146/annurev.psych.53.100901.135153.

Escobar-Rodriguez, T., \& Monge-Lozano, P. (2012). The acceptance of Moodle technology by business administration students. Computers \& Education, 58(4), 1085-1093. https://doi.org/10.1016/j.compedu. 2011.11.012.

Essel, D., \& Apeanti, W. O. (2017). Factors affecting university students' use of Moodle: An empirical study based on TAM. International Journal of Information and Communication Technology Education, 13(1), 14-26. https://doi.org/10.4018/ijicte.2017010102.

Esteban-Millat, I., Martiinez-Loopez, F. J., Pujol-Jover, M., Gaazquez-Abad, J. C., \& Alegret, A. (2018). An extension of the technology acceptance model for online learning environments. Interactive Learning Environments, 26(7), 895-910. https://doi.org/10.1080/10494820.2017.1421560.

Finch, J. F., \& Graziano, W. G. (2001). Predicting depression from temperament, personality, and patterns of social relations. Journal of Personality, 69(1), 27-55. https://doi.org/10.1111/1467-6494.00135.

Fishbein, M., \& Ajzen, I. (1975). Belief, attitude, intension and behavior: An introduction to theory and research. Addison Wesley.

Fornell, C., \& Larcker, D. F. (1981). Evaluating structural equation models with unobservable variables and measurement error. Journal of Marketing Research, 48(1), 39-50. https:/www.jstor.org/stable/3151312.

Galikyan, I., \& Admiraal, W. (2019). Students' engagement in asynchronous online discussion: The relationship between cognitive presence, learner prominence, and academic performance. Internet and Higher Education, 43. https://doi.org/10.1016/j.iheduc.2019.100692.

George, D., \& Mallery, M. (2010). SPSS for Windows step by step: A simple guide and reference, 17.0 update (10th edition). Pearson.

Goldberg, L. R. (1993). The structure of phenotypic personality traits. American Psychologist, 48(1), 26-34. https://doi.org/10.1037/0003-066X.48.1.26.

Gosling, S. D., Rentfrow, P. J., \& Swann, W. B. (2003). A very brief measure of the big five personality domains. Journal of Research in Personality, 37, 504-528. https://doi.org/10.1016/S0092-6566(03) 00046-1.

Gosling, S. D., Rentfrow, P. J., \& Potter, J. (2014). Norms for the ten item personality inventory. Unpublished Data. http://gosling.psy.utexas.edu/wp-content/uploads/2015/09/demographics_for_TIPI_norms.xlsx.

Granic, A., \& Marangunic, N. (2019). Technology acceptance model in educational context: A systematic literature review. British Journal of Educational Technology, 50(5), 2572-2593. https://doi.org/10.1111/ bjet. 12864 .

Graziano, W. G., \& Eisenberg, N. (1997). Agreeableness: A dimension of personality. In R. Hogan, J.A. Johnson and S.R. Briggs (Eds.), Handbook of personality psychology (pp. 795-824). Academic Press.

Ha, I., Yoon, Y., \& Choi, M. (2007). Determinants of adoption of mobile games under mobile broadband wireless access environment. Information Management, 44(3), 276-286. https://doi.org/10.1016/j.im. 2007.01.001.

Hair, J., Anderson, R., Tatham, R. L., \& Black, W. C. (1998). Multivariate data analysis (5th edition). Prentice-Hall. 
Holden, H., \& Rada, R. (2011). Understanding the influence of perceived usability and technology selfefficacy on teachers' technology acceptance. Journal of Research on Technology in Education, 43(4), 343-367. https://doi.org/10.1080/15391523.2011.10782576.

Hrastinski, S. (2009). A theory of online learning as online participation. Computers \& Education, 52(1), 7882. https://doi.org/10.1016/j.compedu.2008.06.009.

Huang, F., Teo, T., \& Zhou, M. (2017). Factors affecting Chinese English as a foreign language teachers' technology acceptance: A qualitative study. Journal of Educational Computing Research, 52(1), 133148. https://doi.org/10.1177/0735633117746168.

Iwasa, H., \& Yoshida, Y. (2018). Psychometric evaluation of the Japanese version of ten-item personality inventory (TIPI-J) among middle-aged, and elderly adults: Concurrent validity, internal consistency and test-retest reliability. Cogent Psychology, 5(1). https://doi.org/10.1080/23311908.2018.1426256.

Jackson, D. L. (2007). The effect of the number of observations per parameter in misspecified confirmatory factor analytic models. Structural Equation Modeling, 14(1), 48-76. https://doi.org/10.1080/ 10705510709336736.

Jansen, R. S., Van Leeuwen, A., Janssen, J., Jak, S., \& Kester, L. (2019). Self-regulated learning partially mediates the effect of self-regulated learning interventions on achievement in higher education : A metaanalysis. Educational Research Review, 28. https://doi.org/10.1016/j.edurev.2019.100292.

John, O. P., \& Srivastava, S. (1999). The big-five trait taxonomy: History, measurement, and theoretical perspectives. In L.A. Pervin and O.P. John (Eds), Handbook of personality: Theory and research (pp. 102-138). Guilford Press.

Johnson, R. D., Hornik, D., \& Salas, E. (2008). An empirical examination of factors contributing to the creation of successful e-learning environments. International Journal of Human-Computer Studies, 66(5), 356-369. https://doi.org/10.1016/j.ijhcs.2007.11.003.

Johnson, A., Ruthven-Stuart, P., \& Smith, A. (2017). Softening the blow: Managing deadlines in online courses. In L. Gomez Chova, A. Lopez Martinez and I. Candel Torres (Eds.), Proceedings of the 11th International Technology, Education and Development Conference (pp. 7596-7604). IATED.

Kamal, A., \& Radhakrishnan, S. (2019). Individual learning preferences based on personality traits in an Elearning scenario. Education and Information Technologies, 24, 407-435. https://doi.org/10.1007/ s10639-018-9777-4.

Kappe, R., \& Van der Flier, H. (2012). Predicting academic success in higher education: What's more important than being smart? European Journal of Psychology of Education, 27(4), 605-619. https://doi. org/10.1007/s10212-011-0099-9.

Kawamoto, T., Oshio, A., Abe, S., Tsubota, Y., Hirashima, T., Itou, D., \& Tani, I. (2015). Age and gender diffrences in big five personality traits: An examination using large-scale cross sectional study data. Japanese Journal of Developmental Psychology, 26(2), 107-122. https://doi.org/10.11201/jjdp.26.107.

King, W. R., \& He, J. (2006). A meta-analysis of the technology acceptance model. Information Management, 43(6), 740-755. https://doi.org/10.1016/j.im.2006.05.003.

Kline, R. B. (2005). Principles and practice of structural equation modeling (2nd edition). Guilford Press.

Komarraju, M., \& Karau, S. J. (2005). The relationship between the big five personality traits and academic motivation. Personality and Individual Differences, 39(3), 557-567. https://doi.org/10.1016/j.paid.2005. 02.013.

Komarraju, M., Karau, S. J., \& Schmeck, R. R. (2009). Role of the big five personality traits in predicting college students' academic motivation and achievement. Learning and Individual Differences, 19(1), 4752. https://doi.org/10.1016/j.lindif.2008.07.001.

Koul, S., \& Eydgahi, A. (2018). Utilizing technology acceptance model (TAM) for driverless car technology adoption. Journal of Technology Management \& Innovation, 13(4), 37-46. https://doi.org/10.4067/ S0718-27242018000400037.

Lee, S., \& Klein, H. J. (2002). Relationships between conscientiousness, self-efficacy, self-deception, and learning over time. Journal of Applied Psychology, 87(6), 1175-1182. https://doi.org/10.1037/0021-9010. 87.6.1175.

Lee, M. K. O., Cheung, C. M. K., \& Chen, Z. (2005). Acceptance of internet-based learning medium: The role of extrinsic and intrinsic motivation. Information \& Management, 42(8), 1095-1104. https://doi.org/10. 1016/j.im.2003.10.007.

Legris, P., Ingham, J., \& Collerette, P. (2003). Why do people use information technology? A critical review of the technology acceptance model. Information Management, 40(3), 191-204. https://doi.org/10.1016/ S0378-7206(01)00143-4.

Lin, C. A., \& Kim, T. (2016). Predicting user response to sponsored advertising on social media via the technology acceptance model. Computers in Human Behavior, 64, 710-718. https://doi.org/10.1016/j. chb.2016.07.027. 
Liu, I.-F., Chen, M. C., Sun, Y. S., Wible, D., \& Kuo, C.-H. (2010). Extending the TAM model to explore the factors that affect intention to use an online learning community. Computers \& Education, 54(2), 600610. https://doi.org/10.1016/j.compedu.2009.09.009.

Lounsbury, J. W., Sundstrom, E., Loveland, J. M., \& Gibson, L. W. (2003). Intelligence, 'big five’ personality traits, and work drive as predictors of course grade. Personality and Individual Differences, 35(6), 12311239. https://doi.org/10.1016/S0191-8869(02)00330-6.

Luyt, I. (2013). Bridging spaces: Cross-cultural perspectives on promoting positive online learning experiences. Journal of Educational Technology Systems, 42(1), 3-20. https://doi.org/10.2190/ET.42.1.b.

Lynn, R., \& Martin, T. (1995). National differences for thirty-seven nations in extraversion, neuroticism, psychoticism and economic, demographic and other correlates. Personality and Individual Differences, 19(3), 403-406. https://doi.org/10.1016/0191-8869(95)00054-A.

Macfadyen, L., \& Dawson, S. (2012). Numbers are not enough. Why e-learning analytics failed to inform an institutional strategic plan. Journal of Educational Technology \& Society, 15(3), 149-163.https://www. jstor.org/stable/jeductechsoci.15.3.149.

Mafuna, L., \& Wadesango, N. (2016). Exploring lecturers' acceptance level of learning management system (LMS) at applying the extended technology acceptance model (TAM). Journal of Social Sciences, 48(12), 63-70. https://doi.org/10.1080/09718923.2016.11893571.

Marshall, S. (2014). Exploring the ethical implications of MOOCs. Distance Education, 35(2), $250-262$. https://doi.org/10.1080/01587919.2014.917706.

Martin, J. H., Montgomery, R. L., \& Saphian, D. (2006). Personality, achievement testscores, and high school percentile as predictors of academic performance across four years of coursework. Journal of Research in Personality, 40(4), 424 431. https://doi.org/10.1016/j.jrp.2005.02.001.

McCrae, R. R., \& Costa, P. T. (1990). Personality in adulthood. Guilford Press.

McCrae, R. R., \& Costa, P. T. (2008). The five-factor theory of personality. In O.P. John, R.W. Robins and L.A. Pervin (Eds.), Handbook of personality: Theory and research (pp. 159-181). Guilford Press.

McElroy, J., Hendrickson, A., Townsend, A., \& DeMarie, S. (2007). Dispositional factors in internet use: Personality versus cognitive style. MIS Quarterly, 31(4), 809-820. https://www.jstor.org/stable/ 25148821.

Moodle (2020). About Moodle. https://docs.moodle.org/39/en/About_Moodle.

Morris, L. V., Finnegan, C., \& Wu, S. (2005). Tracking student behavior, persistence, and achievement in online courses. Internet and Higher Education, 8(3), 221-231. https://doi.org/10.1016/j.iheduc.2005.06.009.

Mortenson, M. J., \& Vidgen, R. (2016). A computational literature review of the technology acceptance model. International Journal of Information Management, 36(6), 1248-1259. https://doi.org/10.1016/j. ijinfomgt.2016.07.007.

Morwitz, V. (2014). Consumers' purchase intentions and their behavior. Foundations and Trends in Marketing, 7(3), 181-230. https://doi.org/10.1561/1700000036.

Mottus, R., Allik, J., Realo, A., Rossier, J., Zecca, G., Ah-Kion, J., et al. (2012). The effect of response style on self-reported conscientiousness across 20 countries. Personality and Social Psychology Bulletin, 38(11), 1423-1436. https://doi.org/10.1177/0146167212451275.

Murillo, G. G., Novoa-Hernandez, P., \& Rodriguez, R. S. (2020). Technology acceptance model and Moodle: A systematic mapping study. Information Development. https://doi.org/10.1177/0266666920959367.

Ngai, E. W., Poon, J., \& Chan, Y. (2007). Empirical examination of the adoption of WebCT using TAM. Computers \& Education, 48(2), 250-267. https://doi.org/10.1016/j.compedu.2004.11.007.

Nistor, N. (2014). When technology acceptance models won't work: Non-significant intention-behavior effects. Computers in Human Behavior, 34, 299-300. https://doi.org/10.1016/j.chb.2014.02.052.

Nov, O., \& Ye, C. (2009). Resistance to change and the adoption of digital libraries: An integrative model. Journal of the American Society for Information Science and Technology, 60(8), 1702-1708. https://doi. org/10.1002/asi.21068.

Olesen, M. H., Thomsen, D. K., Schnieber, A., \& Tonnesvang, J. (2010). Distinguishing general causality orientations from personality traits. Personality and Individual Differences, 48(5), 538-543. https://doi. org/10.1016/j.paid.2009.11.032.

Oshio, A., Abe, S., \& Cutrone, P. (2012). Development, reliability, and validity of the Japanese version of ten item personality inventory (TIPI-J). The Japanese Journal of Personality, 21(1), 40-52. https://doi.org/ 10.2132/personality.21.40.

Pajares, F., \& Schunk, D. H. (2002). Self and self-belief in psychology and education: A historical perspective. In J. Aronson (Ed.), Improving academic achievement: Impact of psychological factors on education (pp. 3-21). Academic Press. 
Park, S. Y. (2009). An analysis of the technology acceptance model in understanding university students' behavioral intention to use e-learning. Educational Technology \& Society, 12(3), 150-162. https://www. jstor.org/stable/jeductechsoci.12.3.150.

Pintrich, P. R. (2000). The role of goal orientation in self-regulated learning. In M. Boekaerts, P.R. Pintrich and M. Zeidner (Eds.), Handbook of self-regulation (pp. 451-502). Academic Press.

Pintrich, P. R., \& De Groot, E. V. (1990). Motivational and self-regulated learning components of classroom academic performance. Journal of Educational Psychology, 82(1), 33-40. https://doi.org/10.1037/00220663.82.1.33.

Pituch, K. A., \& Lee, Y. K. (2006). The influence of system characteristics on e-learning use. Computers \& Education, 47(2), 222-244. https://doi.org/10.1016/j.compedu.2004.10.007.

Poropat, A. E. (2009). A meta-analysis of the five-factor model of personality and academic performance. Psychological Bulletin, 135(2), 322-338. https://doi.org/10.1037/a0014996.

Preacher, K. J., \& Hayes, A. F. (2008). Asymptotic and resampling strategies for assessing and comparing indirect effects in multiple mediator models. Behavior Research Methods, 40(3), 879-891. https://doi.org/ 10.3758/BRM.40.3.879.

Puska, E., Ejubovic, A., Dalic, N., \& Puska, A. (2020). Examination of influence of e-learning on academic success on the example of Bosnia and Herzegovina. Education and Information Technologies. https://doi. org/10.1007/s10639-020-10343-9.

Puzziferro, M. (2008). Online technologies self-efficacy and self-regulated learning as predictors of final grade and satisfaction in college-level online courses. American Journal of Distance Education, 22(2), 72-89. https://doi.org/10.1080/08923640802039024.

Ridgell, S. D., \& Lounsbury, J. W. (2004). Predicting academic success: General intelligence, "big five" personality traits, and work drive. College Student Journal, 38(4), 607-619.

Romero, C., Ventura, S., \& Garcia, E. (2008). Data mining in course management systems: Moodle case study and tutorial. Computers \& Education, 51(1), 368-384. https://doi.org/10.1016/j.compedu.2007.05.016.

Rosen, P. A., \& Kluemper, D. H. (2008). The impact of the big five personality traits on the acceptance of social networking website. AMCIS 2008 Proceedings. 274. https://aisel.aisnet.org/amcis2008/274.

Saade, R. G., Nebebe, F., \& Tan, W. (2007). Viability of the "technology acceptance model" in multimedia learning environments: A comparative study. Interdisciplinary Journal of Knowledge and Learning Objects, 3(1), 175-184.

Sanchez, R. A., \& Hueros, A. D. (2010). Motivational factors that influence the acceptance of Moodle using TAM. Computers in Human Behavior, 26, 1632-1640. https://doi.org/10.1016/j.chb.2010.06.011.

Schepers, J., \& Wetzels, M. (2007). A meta-analysis of the technology acceptance model: Investigating subjective norm and moderation effects. Information and Management, 44(1), 90-103. https://doi.org/10. 1016/j.im.2006.10.007.

Scherer, R., Siddiq, F., \& Tondeur, J. (2019). The technology acceptance model (TAM): A meta-analytic structural equation modeling approach to explaining teachers' adoption of digital technology in education. Computers \& Education, 128(1), 13-35. https://doi.org/10.1016/j.compedu.2018.09.009.

Schmitt, D. P., Allik, J., McCrae, R. R., \& Benet-Martínez, V. (2007). The geographic distribution of big five personality traits: Patterns and profiles of human self-description across 56 nations. Journal of CrossCultural Psychology, 38(2), 173-212. https://doi.org/10.1177/0022022106297299.

Schrire, S. (2006). Knowledge building in asynchronous discussion groups: Going beyond quantitative analysis. Computers \& Education, 46(1), 49-70. https://doi.org/10.1016/j.compedu.2005.04.006.

Short, J., Williams, E., \& Christie, B. (1976). The social psychology of telecommunications. Wiley.

Straub, D., Limayem, M., \& Karahanna-Evaristo, E. (1995). Measuring system usage: Implications for is theory testing. Management Science, 41(8), 1328-1342. https://doi.org/10.1287/mnsc.41.8.1328.

Sumak, B., Hericko, M., \& Pusnik, M. (2011). A meta-analysis of e-learning technology acceptance: The role of user types, and e-learning technology types. Computers in Human Behavior, 27, 2067-2077. https:// doi.org/10.1016/j.chb.2011.08.005.

Surry, D. W., Ensminger, D. C., \& Haab, M. (2005). A model for integrating instructional technology into higher education. British Journal of Education Technology, 36(2), 327-329. https://doi.org/10.1111/j. 1467-8535.2005.00461.x.

Svendsen, G. B., Johnsen, J. A., Almas-Sorensen, K. L., \& Vitterso, J. (2013). Personality and technology acceptance: The influence of personality factors on the core constructs of the technology acceptance model. Behaviour \& Information Technology, 32(4), 323-334. https://doi.org/10.1080/0144929X.2011. 553740 .

Terzis, V., Moridis, C. N., \& Economides, A. A. (2012). How student's personality traits affect computer based assessment acceptance: Integrating BFI with CBAAM. Computers in Human Behavior, 28, 19851996. https://doi.org/10.1016/j.chb.2012.05.019. 
United Nations (2020). Policy Brief: Education during COVID-19 and beyond. https://unsdg.un.org/resources/ policy-brief-education-during-covid-19-and-beyond.

Van Raaij, E. M., \& Schepers, J. J. L. (2008). The acceptance and use of a virtual learning environment in China. Computers \& Education, 50(3), 838-852. https://doi.org/10.1016/j.compedu.2006.09.001.

Venkatesh, V. (2000). Determinants of perceived ease of use: Integrating control, intrinsic motivation, and emotion into the technology acceptance model. Information Systems Research, 11(4), 342-365. https:// www.jstor.org/stable/23011042.

Venkatesh, V., \& Davis, F. D. (2000). A theoretical extension of the technology acceptance model: Four longitudinal field studies. Management Science, 46(2), 186-204. https://doi.org/10.1287/mnsc.46.2.186. 11926.

Vermetten, Y. J., Lodewijks, H. G., \& Vermunt, J. D. (2001). The role of personality traits and goal orientations in strategy use. Contemporary Educational Psychology, 26(2), 149-170. https://doi.org/10. 1006/ceps.1999.1042.

Wang, W., Hsieh, P. A., \& Song, B. (2012). Understanding user satisfaction with instant messaging: An empirical survey study. International Journal of Human-Computer Interaction, 28(3), 153-162. https:// doi.org/10.1080/10447318.2011.568893.

Weerasinghe, S., \& Hindagolla, M. C. B. (2018). Technology acceptance model and social network sites (SNS): A selected review of literature. Global Knowledge, Memory and Communication, 67(3), 142-153. https://doi.org/10.1108/GKMC-09-2017-0079.

Wu, B., \& Chen, X. (2017). Continuance intention to use MOOCs: Integrating the technology acceptance model (TAM) and task technology fit (TTF) model. Computers in Human Behavior, 67, 221-232. https:// doi.org/10.1016/j.chb.2016.10.028.

Yeou, M. (2016). An investigation of students' acceptance of Moodle in a blended learning setting using technology acceptance model. Journal of Educational Technology Systems, 44(3), 300-318. https://doi. org/10.1177/0047239515618464.

You, J. W. (2016). Identifying significant indicators using LMS data to predict course achievement in online learning. Internet and Higher Education, 29(1), 23-30. https://doi.org/10.1016/j.iheduc.2015.11.003.

Zhou, M. (2016). Chinese university students' acceptance of MOOCs: A self-determination perspective. Computers \& Education, 92-93, 194-203. https://doi.org/10.1016/j.compedu.2015.10.012.

Zhou, T., \& Lu, Y. (2011). The effects of personality traits on user acceptance of Mobile commerce. International Journal of Human-Computer Interaction, 27(6), 545-561. https://doi.org/10.1080/ 10447318.2011 .555298 .

Zimmerman, B. J. (2000). Self-efficacy: An essential motive to learn. Contemporary Educational Psychology, 25(1), 82-91. https://doi.org/10.1006/ceps.1999.1016.

Publisher's note Springer Nature remains neutral with regard to jurisdictional claims in published maps and institutional affiliations. 